\title{
S Research Square

\section{Anti-viral effect of Indigoferra gerardiana on core protein of HCV and clinical significance of serum markers in chronic HCV genotype 3a patients in district Peshawar}

Shahina Mumtaz ( $\nabla$ drshahinakmc@gmail.com )

Khyber Medical College Peshawar

Jawad Ahmed

Khyber Medical University

Shafiq Ahmad Tariq

Khyber Medical University

Waheed Iqbal

Khyber Medical College

Sami Siraj

Khyber Medical University

Muhammad Asghar

Khyber Medical College

Tahir Sarwar

Khyber Medical University

Noor Rehman

khyber Teaching Hospital

Research

Keywords: HCV, Genotypes, viral load, IG, Core gene, anti-viral therapy

Posted Date: February 12th, 2020

DOI: https://doi.org/10.21203/rs.2.23383/v1

License: @ (i) This work is licensed under a Creative Commons Attribution 4.0 International License.

Read Full License 


\section{Abstract}

Background/aim: Hepatitis C virus (HCV) disease is a health challenge due resistance cases globally. Many plant-derived natural compounds have demonstrated antiviral effects. These plants can provide an alternative way to new antiviral. Core protein of HCV has ability to interact with a wide range of viral and cellular proteins, including proto-oncogenes.

Materials and Methods: In this cross-sectional study, total of 421 Hepatitis C Virus (HCV) positive patients were subjected by Polymerase Chain Reaction (PCR). The correlation of genotype with continuous and categorical variables was analyzed. Furthermore, antiviral activity of indigoferra gerardiana (IG) was tested against core protein of HCV. The amplified complete core protein of HCV genotype 3a was sequenced and cloned. IG was extracted and screened against core protein of HCV 3a genotype in cell line.

Results: Genotype 3a was the common genotype type of HCV ( $n=363,86 \%)$. Significant differences were observed in viral load among 3a genotype of HCV (< P 0.05). Frequently detected age group was 21-40 (59.4\%) Sex and age were statistically associated with HCV infection (49\% males and $37 \%$ in females). The results of RT-PCR demonstrated that methanolic extract of IG showed $57 \%$ reduction of infecting cells.

Conclusions: Methanolic extract of IG showed good antiviral activity i.e. 57\% reduction of infecting cells.

\section{Introduction}

Hepatitis $C$ disease is a worldwide burden that globally affects about 170 million people [1],[2]. Viral clearance was seen in majority of patients. Approximately $60-80 \%$ of acute HCV infection persists and may progress into chronic disease. Liver cirrhosis develops by chronic hepatitis $\mathrm{c}$ within 10 to 20 years in 10 to $20 \%$ of patients. Each year approximately 1 to $5 \%$ of these patients are at risk of developing HCC [3]. Certainly, many studies reported the high incidence of HCV as worldwide threat [4]. Clinical findings, viral load and genotypes are basis for HCV infective patients during antiviral therapy [5]. Previous studies tried to relate viral factors (viral load, genotype) and host biochemical factors (AST, ALT and bilirubin) and their relation with liver damage, but no clear outcome were found. HCV is a single-stranded RNA. It encodes polyprotein of 3010 residues. The essential components are the structural proteins (core, E1, E2) and seven nonstructural proteins (p7, NS2, NS3,NS4A, NS4B, NS5A, NS5B) [6]. On the basis of nucleotide heterogeneity, $\mathrm{HCV}$ is classified into different genotypes. Genotypes 1 and 3 are circulating world-wide. In Pakistan, genotype $3 \mathrm{a}$ is the predominant genotype [7]. Highly conserved, core protein of HCV, encapsidates the genomic RNA. The core protein comprises of basic $\mathrm{N}$-terminal and hydrophobic $\mathrm{C}$ terminus anchors the endoplasmic reticulum. The core protein is translated as an immature protein $(22 \mathrm{kDa})$ and mature protein of $21 \mathrm{kDa}$ due to additional cleavage [8]. The in vitro and invivo studies suggested that core proteins have effect on immune suppression, oxidative stress, carcinogenesis, 
steatosis, cell metabolism and lipid metabolism [9]. In patients with chronic HCV, hepatic steatosis developed at a high rate and a close correlation has been noted with intra-hepatic core protein expression level. The growth signaling is disregulated by core protein $[10,11]$. Core protein inhibited interferon- $a$ induced nuclear import of STATs [12].

Combination therapy with peg IFN- $a$ and ribavirin is recommended therapy for HCV infection [13]. In some patients, IFN-based therapies are limited by side effects and incomplete response rates, leading to early termination of treatment. The drugs like telaprevir / boceprevir are also given as protease inhibitors for $\mathrm{HCV}$ infection. This regimen clears infections more than $70 \%$ in HCV genotype- 1 infected patients. However drug resistant variants were found to be developed with DAAs [14-16]. Further studies introduced sofosbuvir and simprevir (next generation DAAs) $[17,18]$. Some studies reported that various HCV proteins (Core, NS3/4A, E2 and NS5A/5B) provokes antiviral effect of IFN-a [19]. HCV core protein also inhibits nuclear translocation of STAT-1 and IFN induced phosphorylation. [20, 21]. The main target of therapy is to remove the virus and stop complications. The desired outcome of therapy is monitored by SVR [22]. The drug resistant viral species may arises by the use of DAAs against HCV [23]. Many studies are looking for new ways of drug therapy that are used against HCV infection. Different medicinal plants and their phytochemicals have potential uses in HCV therapy. These plants are less toxic, cost effective, easily accessed and have multiple target activities. The phenolic extract obtained from Marrubium peregrinum (Lamiaceae) showed inhibitory effect of flavonoid derivatives, ladanein (BJ486K) on postattachment entry of HCV with an IC50 value $(2.5 \mu \mathrm{mol})$ into cultured hepatocytes of human. The inhibitory effect of BJ486K was independent of HCV genotype. Combination of cyclosporine and BJ486K had a synergistic effect in inhibition of HCV infection [24]. Another study reported that the cytotoxic, antitumor and antioxidant effects of Methanolic Extract of I cassioides (MEIC) was evaluated [25]. The IG is generally recognized as Ghoreja, this species of flowering plant belongs to Family Fabaceae (Leguminosae) and its sub-family Faboideae. It is used for relieving abdominal colic and the infectious diseases especially bacterial infections involving skin [26]. In Pakistan, the IG is found in hilly region of Khyber Pakhtunkhwa, Azad Jammu Kashmir, Northern areas of Upper Dir. I.blongifolia possesses antimicrobial, hepatoprotective and lipoxygenase activity [27]. I.aspalathoides effectively suppresses liver tumor induced by DEN and also used against HCV, The flavonoid of I barberi Gamble showed the hepatoprotective effect with histopathological evidence in liver injury caused by paracetamol in rats. Similarly, another specie of Indigoferra i.e I linnaei. demonstrates the potent antitumor and cytotoxic properties [28]. In another research, the flavonoid fraction of methanolic extract of I.tinctoria has been reported to have chemo protective effect against lung cancer [29]. So based on supported links regarding targeted anti-viral activity the current study is carried out to explore another specie Indigoferra gerardiana (IG) for possible antiviral activity [30],[31], [32], [33], [34], [35].

The present study was conducted to evaluate the correlation between LFT's, viral loads and the severity of liver damage in chronic HCV patients and antiviral activity of Indigoferra gerardiana.

\section{Materials And Methods}


This current study was designed at the Institute of Basic Medical Science (IBMS) Peshawar, Khyber Teaching Hospital, Peshawar, Institute of Biotechnology and Genetic Engineering, Agriculture University Peshawar, Center of Applied and Molecular Biology Lahore. The study duration was 12 months (Jan 2018 to Feb 2019). The institutional ethical committee at the Institute of Basic Medical Science, Peshawar and Institutional Research and Ethical Review Board of Khyber Teaching Hospital approved the study.

Samples Collection and Processing

A total of 421 RNA positive samples (male: 207, female: 156) of chronic HCV infected individuals at Khyber Teaching hospital, Khyber medical college and Khyber medical university Peshawar, KP-Pakistan were selected. Questionnaire was taken from patients who came for HCV initial screening. Informed consent was taken from these patients. The patient responsive to treatment, patient's not giving informed consent and cannot come for follow-up visits were excluded from study. After blood sampling, serum was stored in a refrigerator at $-80^{\circ} \mathrm{C}$. A baseline investigation along with genotyping and viral load quantification was done. HCV RNA was detected using quantitative PCR (Q-PCR) according to the operating manual of the test kit (Qiagen, Germany) followed by HCV genotyping [36]. The routine LFTs were assessed for each patient in the hospital laboratory. Furthermore, biochemical tests (ALT, AST, bilirubin) were correlated with viral factors (genotype, viral load). The results were expressed as mean \pm S.D (standard deviation) or as percentage. The correlation between categorical variables were assessed using the Chi Square, it was applied to evaluate differences in proportions using SPSS 20.0 software (SPSS Inc., USA). The P value ( $<0.05$ ) was labeled significant. HCV genotype determination was carried out as described earlier [36]. For HCV genotype determination, RNA extraction was carried according kit protocol. Isolated RNA was reverse transcribed into complementary DNA (cDNA). The cDNA was amplified in two rounds of type specific nested PCR for isolation of genotype specific PCR product.

\section{Extraction of RNA}

Viral RNA was extracted from HCV positive serum of genotype 3a. For extraction, RNA extraction was used as per kit protocol. RNA was immediately stored at $-80^{\circ} \mathrm{C}$ for further analysis.

\section{cDNA synthesis}

Complementary DNA (cDNA) was synthesized (Invitrogen CDNA protocol kit) by RT PCR using reverse primers. Briefly, $04 \mu \mathrm{l}$ RNA and $1 \mu \mathrm{l}$ of Outer Antisense (OAS) primer was mixed and incubated at $65^{\circ} \mathrm{C}$ for $5 \mathrm{~min}$ and kept immediately on ice. Then $4 \mu \mathrm{l} 5 \mathrm{x}$ buffer, $2 \mu \mathrm{l} 10 \mathrm{mM}$ dNTP's, $1 \mu \mathrm{l}$ RNAase inhibitor and $1 \mu \mathrm{l}$ reverse transcriptase enzyme was added to a final volume of $15 \mu \mathrm{l}$. Mixture was kept in thermal cycler at $42^{\circ} \mathrm{C}$ for 60 minutes and then termination of reaction at $70^{\circ} \mathrm{C}$ for 10 minutes.

Conventional PCR for Core Gene Detection 
For amplification of HCV Core gene, forward (5'ATGAGCACACTTCCTAAACC3') and reverse primers (5'GACGTATTCCGCCACTCTAG3') were used for amplification. PCR was done in a total reaction volume of $15 \mu$ including $2 \mu \mathrm{l}$ of CDNA, reverse primer $1 \mu \mathrm{l}$, forward primer $1 \mu \mathrm{l}$, Master mix (Invitrogen) $7.5 \mu \mathrm{l}$ and distilled water $3.5 \mu \mathrm{l}$. Mixture was kept in the thermal cycler and the temperature was set for initial denaturation at $95^{\circ} \mathrm{C}$ for $5 \mathrm{~min}$, and then 36 cycles each consisting of denaturation at $95^{\circ} \mathrm{C}$ for $0.25 \mathrm{sec}$, annealing done at $55^{\circ} \mathrm{C}$ for $30 \mathrm{sec}$ and elongation at $72^{\circ} \mathrm{C}$ for $1 \mathrm{~min}$. Final extension was carried out at $72^{\circ} \mathrm{C}$ for $10 \mathrm{~min}$.

Gel electrophoresis

The amplified gene specific PCR product (573 bp) was resolved on 1.5\% agarose gel (Thermo Fisher Scientific, USA). By using a 100 bp DNA ladder (Fermentas, USA) It was visualized under UV illumination. (Uvitec Limited, Cambridge, UK). The confirmed PCR product was eluted by protocol of kit (Novel Gel/PCR DNA Purification Mini Kit)

Sequencing and Cloning of Core gene

Amplification

For molecular genomic analysis, one sample with high viral titer was selected for isolation and amplification of structural gene. The amplified, sequenced purified PCR product was cloned in pDNA2.1 TA cloning Kit (TOPO TA Cloning Kit Lot no 1506821-invitrogen)

Primer Designing

For amplification of core gene from plasmid both forward (GCGATATCATGAGCACACTTCCTAAA) and reverse (AATCTAGATCATGGCTGCTGGATGAAT) primers were designed. For cloning, primers had restriction sites for EcoRV and Xba1. In all the primers, the start codon was present in the Flag TAG sequence and a stop codon for translation termination was incorporated. The PCR positive clones were used for further confirmation analysis by restriction digestion of the plasmid containing core gene.

Cloning in mammalian expression vector pcDNA3.1

The amplified PCR product was cloned into mammalian expression vector pcDNA3.1. By continuous heat shock, ligation product was transformed into DH5a E Coli (competent cells) Transformed cells were allowed to proliferate for $120 \mathrm{~min}$ and incubated at $37^{\circ} \mathrm{C}$ with shaking. A total of $0.2 \mathrm{ml}$ of the growth medium was spread on fresh LB/AMP and Kanamycin plates. Transformed colonies appeared blue and white after overnight incubation at $37^{\circ} \mathrm{C}$. Confirmed clone was sequenced with Big Dye Deoxy Terminator method using vector specific universal outer sense and inner sense primers (UOS, UIS) followed by bidirectional sequencing in DNA sequence (Applied Biosystems).

Collection and extraction of medicinal plant 
The leaves of Indigoferra gerardiana (IG) were collected from northern area of KPK, confirmed by the Botany department of Peshawar university. The leaves were shade dried, segregated and crushed in grinder to form coarse powder. Methanol was added at the ratio of 1:20 (w/v) and was macerated for $72 \mathrm{hrs}$. Whartsman filter paper (no-1/ cloth filter) was used for the filtration of supernatant. The solvent was evaporated using a vacuum rotary evaporator (Heidoloph Rotavapor) under controlled temperature $\left(40{ }^{\circ} \mathrm{C}\right)$ and reduced pressure (204 mbar). Double extractions was done for the collection of residue [37]. Methanolic extract was further fractionized on the basis of polarity, in $n$-hexane, chloroform and acetone. The results revealed that viral titer was blocked by acetone extract to a greater extent.

Stock solution preparation

The dried plant extract (100 mg) was suspended in $01 \mathrm{ml}$ of Dimethylsulfoxide (DMSO) for stock concentration $(100 \mathrm{mg} / \mathrm{ml})$. Then make dilutions in $5 \%$ DMSO $\left(5 \mathrm{ml} \mathrm{DMSO}+95 \mathrm{ml} \mathrm{H}_{2} \mathrm{O}\right)$ inside the laminar flow hood sieving (by using 0.22 um filter) done of the above solution and stored at $\left(-20^{\circ} \mathrm{C}\right.$ ).

Cell lines

The Huh-7 cell line (University of Lahore) was cultured in Dulbecco's modified Eagle medium (DMEM). It was supplemented with $100 \mu \mathrm{g} / \mathrm{ml}$ streptomycin, fetal bovine serum $(10 \%)$ and penicillin $(100 \mathrm{iu} / \mathrm{ml})$ at $37^{\circ} \mathrm{C}$ in an atmosphere of $\mathrm{CO}_{2}(5 \%)$.

MTT Assay for Toxicity

Toxicological effect was determined through MTT assay. In living cells, the MTT substance is reduced to purple formazan crystals (insoluble in water) by mitochondrial succinic dehydrogenases. The absorption of dissolved formazan correlates with the number of alive cells. To determine the cellular toxicity, different concentrations of herbal extract was added into 96 -well plates $\left(2 \times 10^{4}\right.$ cells/well $)$, the plate was incubated $\left(37^{\circ} \mathrm{C}\right)$ in an atmosphere of $\mathrm{CO}_{2}(5 \%)$ and sealed in aluminum foil for $24 \mathrm{hrs}$. At end of extraction, test compounds and media were removed. $20 \mu \mathrm{l}$ of MTT solution ( $5 \mathrm{mg} / \mathrm{ml}$ in PBS) and fresh media $(100 \mu \mathrm{l})$ were added to all wells. The plate was wrapped in aluminum foil and then it was incubated at $37^{\circ} \mathrm{C}$ for 04 hours. DMSO of $100 \mu \mathrm{l}$ was added to dissolve the formazan crystals after media was removed. MTT-formazan product was accessed by measuring absorbance-reader at a test wavelength of $570 \mathrm{~nm}$ by Enzyme Linked Immunosorbent Assay (ELISA) plate.

Analysis of plant extracts in cell line

To establish, in-vitro replication of HCV, -Huh-7 cell line was used. The same protocol was used for viral inoculation as done by Rehman S in 2011. In these experiments, HCV patients of 3a genotype with high viral titer $>1 \times 10^{9} \mathrm{iu} / \mathrm{ml}$ was used as inoculums. Huh-7 cells were maintained in six well culture plates and washed two times with serum-free medium. Different concentrations of drug containing medium was added to the cell culture replaced after every $24 \mathrm{~h}$. after incubation at $370 \mathrm{C}$ for $48 \mathrm{~h}$, DMEM containing MTT at the final concentration of $1 \mathrm{mg} / \mathrm{ml}$ was added to each well, after $1 \mathrm{~h}$ of it was replaced with 
100 ul of DMSO to solubilize the formazan crystals. Using spectrophotometer, the surviving cells of each well were measured at $570 \mathrm{~nm}$ by optical density (OD) (30). Transfected cells were maintained in $5 \% \mathrm{CO}_{2}$ for $24 \mathrm{~h}$ at $37^{\circ} \mathrm{C}$. On next day, adherent cells were washed 03 times with $1 \times$ PBS buffer, medium was added and again incubated for $48 \mathrm{hrs}$. Cells were harvested and assessed by RT-PCR. To analyze the effect of medicinal plant extracts on HCV, transfected Huh-7 cells were seeded after 02 days of infection in 24 well plates in both absence and presence of herbal extracts which were then grown to 80 percent confluence. The cells viability was noted after $24 \mathrm{hrs}$. Cells were then lysed by cell lysis solution containing $5 \mu$ internal control (Sacace, Italy). RNA pallet was solubilized in 1\% DEPC (Diethyl Pyro Carbonate) treated water. HCV RNA quantifications were determined by RT-PCR using kit protocol.

Effect of IG extract on gene expression in cell line through Real Time PCR

The anti-viral effect of plant extract on HCV core gene were detected by using specific-primers of HCV core genes via quantitative PCR (Fermentas, USA). The GAPDH gene was used ror internal control. Each RT PCR assay was performed in triplicate.

Components and concentrations of PCR reaction

To analyzed the anti-viral effect of plant extract on HCV core gene, from transfected Huh-7 cells. Semiquantitative RT PCR product was amplified by using forward and reverse primers of the GAPDH and primer of the HCV Core gene under controlled condition. The PCR products were subjected to electrophoresis. Briefly, reagents of PCR were; PCR product-2ul, 10xPCR buffer $2.5 \mathrm{ul}, \mathrm{Mgcl}_{2}-2 \mathrm{ul}$, dNTPs $(10 \mathrm{mM}) 2 \mathrm{ul} . c 0 r e$, outer reverse primer $1 \mathrm{ul}$, core inner forward primer $1.0 \mathrm{ul}$ and Taq polymerase-1.0 ul, dist water was added to reaction mixture to make volume up to $20 \mathrm{ul}$.

\section{Results}

Distribution of HCV genotype in chronic HCV patients

The results of the current research work revealed that out of $421 \mathrm{HCV}$ positive patients, genotype HCV 3a was predominant $(86 \%)$, followed b1a (08\%), untypable $(03 \%), 1 \mathrm{~b}(01 \%), 3 \mathrm{~b}(0.20 \%)$, and mixed cases were $0.40 \%$. Out of patients, 241 were male and 180 patients were female while the high number of patients (389) were in age group of 20-40 years (table I).

Liver function test in HCV Genotype

The results of liver function test of HCV revealed that $85.7 \%$ (361/421) of patients demonstrated normal values while $14 \%$ (59/421) showed abnormal liver function tests. No significant correlation was recorded between LFT's and HCV genotypes $(p=>0.05)$ as shown in table II.

Viral load of HCV in genotype 3a 
The present study reported that the HCV RNA viral load was detected in 363 patients having genotype 3a. Out of 363 patients, 273 had high viral load $(>800,000)$ and 90 patients had viral load less than 800,000. The $P$ value of significant difference $(p<0.05)$ was calculated using chi square test (table III).

PCR amplification of core gene

The core gene of HCV was amplified by optimized conditions of the primers. Amplified product was resolved on TBE agarose gel (1.5\%) with DNA marker (100 bp) as presented in figure I.

Blast Analysis

Chromas and Bioedit-software were used on sequencer generated files. In FASTA format samples were copied and analyzed through Blast software.

Sequence Translation

After sequencing, the obtained nucleotide sequences by using Expasy software were translated into amino acid sequences. The obtained open reading frame of amino acids was further considered for expression analysis. Through Blast software, further confirmation was carried out by protein Blast as shown in figure II.

Cellular Toxicity through MTT cell proliferation assay

Before assessing the antiviral activity of IG on cell viability, the effects on cell line were evaluated. For this purpose, MTT calorimetric and cell counting assay was employed. Serially diluted different concentrations of the herbal extracts were incubated with Huh-7 cell line. Absorbance readings were taken after incubation using microplate spectrophotometer. The results of cytotoxicity of effective extract were found at nontoxic dose of $100 \mu \mathrm{g}$ (figure III). For assessing the anti-HCV activity of extract IG, cell lines were transfected and incubated for $24 \mathrm{~h}$. After incubation, expression of gene of interest was detected by the Q-PCR assay (figure IV) and relative to the levels of cells incubated without compound (control).

Anti-viral activity of extract of IG against HCV Infected cell line

The solvent extract from IG was tested against core gene of HCV to determine the antiviral activity. The results of RT-PCR revealed that IG showed good antiviral activity against HCV i.e. IG inhibited $57 \%$ of cell line at nontoxic concentration as shown in figure $\mathrm{V}$.

Methanolic extract of IG in different solvents

Methanolic extract of IG was fractionized by different solvents, based upon their polarity content (nhexane, chloroform, and acetone) while acetone extract inhibited viral titer on large scale as shown in figure $V$. 


\section{Discussion And Conclusions}

$\mathrm{HCV}$ is a highly prevalent, blood- borne pathogen. Patients infected with HCV have various clinical results, which ranges from acute resolving hepatitis to chronic liver disease (hepatocellular carcinoma or liver cirrhosis). [38]. Almost $80 \%$ HCV patients develop chronic infection and in about $20 \%$ of these subjects, progression to cirrhosis occurs [39]. Liver disease develops slowly over numerous decades in most of the patients. In Pakistan, chronic HCV is a foremost healthcare challenge resulting liver inflammation, tissue scarring, liver cirrhosis and HCC without treatment [40,41]. Many studies conducted to determine the relationship between severity of biochemical abnormalities and serum viral load and they have produced contradictory results.[42]. Although raised serum level of ALT and AST levels indicate liver damage, in $20-30 \%$ of patients of chronic HCV, the S. AST and ALT levels return back to normal within 12 weeks of infection in spite of progression of disease. Few studies revealed that most of the patients with normal or near normal S.ALT levels, show mild liver lesion on histology and have slow progression of the disease. Some researchers revealed no relation between serum ALT, HCV viral load and the level of hepatic damage while others found major relation between HCV RNA load, serum ALT and degree of hepatic inflammation [43]. As PCR is pricey technique as compare to LFTs, so the current study was conducted to evaluate the relation between LFTs, liver damage severity and serum HCV RNA positivity in chronic HCV patients. Our results of LFT's of HCV showed that $85.7 \%$ (361/421) of patients demonstrated normal values while $14 \%$ (59/421) showed abnormal liver function tests. No significant correlation between LFT's and HCV genotypes $(p=>0.05)$ was reported. A similar study was conducted in which no significant difference was recorded in LTF's and genotypes of HCV infected patients. Similar observation was also noted in our study $(p=>0.05)$. Another finding in the same study was a useful correlation of viral loads with genotypes of HCV which is in accordance with our study results showing significant correlation of genotype 3a with HCV Viral load $(p<0.05)$ The increase incidence of HCV is found in Intravenous Drug Users (IDUs). Majority of people acquire this infection through reuse of syringes, needles and lack of sterilization practices in IDUs. We observed that there is increase prevalence of hepatitis c disease in males in comparison to female (207, 156 respectively). These observations may also be attributed to the IDU, as males were more affected [44] [45]. Also there is more exposure of males to the environment as compared to females, in our area of study, which may be another contributing factor and hence males were main target. A study conducted in 2014, had got similar results. They had showed that hepatitis c patients with higher levels of ALT have more active immune response to chronic viral infection [46]. To give reason for the poor association between the severity of liver damage and ALT level is not very simple. It was proposed in general terms that hepatocytes apoptosis has an important role. Liver damage and the loss of hepatocytes by apoptosis, could occur in hepatitis c-infected cases without changes in ALT level. ALT is released either by an immune mediated mechanism or by direct cytopathic effect of virus. Few studies suggested that the immune response in hepatitis $c$ infected patients, with persistent normal ALT levels is less activated than in cases with abnormal ALT levels.[1].As hepatitis $C$ infection is also related with several extra hepatic manifestations involving renal system, cutaneous, haemopoietic and neurologic system. Many autoimmune phenomenons are observed in these patients. Autoimmune hemolytic anemia (AlHA) was observed in HCV genotype 4 [47]. 
If baseline viral load is less than 399,000-850,000 IU/mL, the course of treatment, in genotype- 1 and 4 may be reduced to 24 weeks and to 12-16 weeks in genotype 2 or 3 individuals. [48]. Many researchers have also observed that low viral load $(599,000-799,000 \mathrm{IU} / \mathrm{mL})$ is a good indicator of SVR. SVR decreases with elevation in viral load [49]. In deciding the response of host to antiviral therapy, viral genotypes have played a very important role. These genotypes and subtypes of HCV have variables that are distributed world widely. In Europe and United States, the genotype $1 \mathrm{a}$ and $1 \mathrm{~b}$ are prevalent, respectively. In Africa countries, genotype 4 is present while HCV genotype 2 is abundantly found in West Africa countries and genotype 3a in Australia and South Asia. Apart from that, Asia and South Africa have genotypes 5 and 6 , respectively. All these genotypes of HCV exhibit $30 \%$ heterogeneity in their nucleotide sequences. With the passage of time, the presence of HCV genotypes changes in Pakistan. The epidemiological studies may expose the distribution pattern of HCV genotype in order to facilitate the preventive strategies and treatment alternatives [50].

The HCV infection is the health challenge for clinicians globally. The main objective of the WHO is to reduce incidence of hepatitis by $90 \%$ and to reduce mortality by $65 \%$ by 2030 [51].In Asia and Africa, highest prevalence was observed [2].In Asia-pacific regions, the distribution pattern is inconsistent from 4-12\%. [52, 53]. About 10 million people have been infected with HCV in Pakistan [54]. The prevalence rate vary in China, from 1\% 31.86\%.[55], while in Saudi Arabia the prevalence rate is 1.8\% [56].

There is significant prevalence of HCV infection and till now no vaccine available. Lack of less compatibility of antiviral therapy and virus specific treatment opens the gateway to explore and use the medicinal plants for treatment. Currently, available agents target the NS3-4A protease and NS5B polymerase but still there is a chance of high resistance. Various studies are being conducting for new treatment options against HCV infection to overcome this alarming situation and to discover other imminent viral targets.

In this study, we investigated antiviral compounds of plant extract against HCV core protein to detect potential antiviral agents. The extracts of IG and its fractions were analyzed against HCV core protein for their antiviral activity. The core protein has 3 domains; 1 st basic domain (aa 1-117) involves in binding to the viral RNA, 2nd less basic (118-174 aa) links with the lipid droplet and 3rd domain confines between 175-aa 191aa. Two forms of core protein i.e. the longer form p21 and the shorter form p19 which is derived from $\mathrm{p} 21$, have been identified [57].

A methanolic extract of leaves when evaluated with RT-PCR revealed the evidence of showing antiviral activity against HCV RNA expression. Specifically targeting steps of HCV life cycle in infected cells is a good approach for the development of new antiviral. The flavonoid (Apigenin) has diverse biological effects that includes improvement of the cancer cell response to chemotherapy [58], anti-platelet activity and tumorigenesis present in many vegetables and fruits [59-61]. Apigenin also the block the maturation of a subset of miRNA. [62]. The inhibitory acitivity of Apigenin on HCV replication was reported in 2018 [63]. Herbs have a key role in managing different disorders of liver. Due to diverse pharmacological 
effects such as hepatoprotective and antioxidant activity, plants derived products (flavonoid, steroids and terpenoids) have gained considerable attention in recent years $[64,65]$

Pakistan has tested (in vitro) numerous medicinal plants i.e. glycyrrhizin (GL) in recent years, that have inhibitory effects on HCV titer. It also showed synergistic effects with IFN. GL have been recommended as a future drug to help in decreasing the viral titer of HCV because it inhibited the core protein of genotype $3 a$ at the mRNA [66]. The same research group have tested another plant (Silybum marianum (SM)) and confirmed through western blotting technique that two of its fractions exhibited inhibition of HCV core protein of genotype 3a. The researchers proposed that the combination of SM with IFN shows synergistic results in treatment of HCV [67]. It was possibly explained that a component of miRNA-generating complexes through impaired mitogen activated protein kinase activation Micro RNA122 (miR122), are essential for the HCV RNA stability and propagation by decreasing the levels of mature miR122 through the inhibition of the phosphorylation of TRBP. Many studies are still in progress that are looking for new ways of drug therapy against HCV infection. On cell viability effects the antiviral activity of IG were evaluated by incubating serially dilutes extracts along with transfected Huh-7 cells. MTT calorimetric and Cell counting assay was employed. By using the above mentioned assays the results of cytotoxicity assessment of effective extracts were found non-toxic at a concentration of $100 \mu \mathrm{g}$ dose. The fractionation of methanolic extract of IG leaves into different solvents leads to the further specification. Assay was done similar to Rehman et al in 2011. The results revealed that acetone IG extract direct inactivated HCV. The natural products are small molecules that have capability of being absorbed and drug like activity are biologically active in different assays. The expanse of such medicines are much cost effective than that of producing through combination chemistry. Various herbal plants have been used for different infectious diseases globally and still more effective. The identify the molecular targets and structure-activity correlation, are mandatory in order to depict conclusion.

Our study concludes that HCV 3a genotype is highly prevalent in Peshawar, Pakistan. Due to poverty in Pakistan, doctors generally do not suggest the genotype testing. Importance of genotyping cannot be neglected. This study revealed that there is no relationship between liver function test and the grade of activity or fibrosis stage of liver in chronic HCV patients. The results of RT-PCR revealed that methanolic extract of IG showed more than $50 \%$ reduction of infecting cells. By selecting different molecular targets, specific structure relation can be obtained. To establish the importance of IG as antiviral drug against $\mathrm{HCV}$, further research is required for the recognition and isolation of antiviral compound in IG.

\section{Declarations}

\section{Ethics approval and consent to participate}

The current study was approved by ASRB at the Institute of Basic Medical Science, Peshawar and IRB of Khyber Teaching Hospital approved the study. The patient provided consent for the current study.

\section{Consent for publication}


Written informed consent was obtained from the patient for the current study.

\section{Availability of data and materials}

All data generated or analyzed during this study are included in the current study.

\section{Competing interests}

The authors declare that they have no competing interests.

\section{Funding source}

This research was not funded by any funding agency, public, commercial or not-for-profit organization.

\section{Author's contributions}

Study concept and design, Shahina Mumtaz, Jawad Ahmed, Shafiq Ahmad Tariq; analysis and interpretation of data; Shahina Mumtaz, Waheed Iqbal, Sami Siraj, Tahir Sarwar, drafting of the manuscript; Shahina Mumtaz, Shafiq Ahmad Tariq, Waheed Iqbal, Sami Siraj, Tahir Sarwar; critical revision of the manuscript; Shahina Mumtaz, Jawad Ahmed, Shafiq Ahmad Tariq, Noor Rehman

\section{Acknowledgements}

We also appreciate Mr. Ali Said and Mr. Muhammad Imran for providing technical help in our laboratory work, storage and take care of study samples.

\section{Abbreviations}

ALT: Alanine transaminase; AST: Aspartate amino transaminase; HCV: Hepatitis C virus; IRB: Institutional Review Board; ASRB: Advanced study review board; HCV: Hepatitis c virus; PCR: Polymerase chain reaction; Q-PCR: Quantitative polymerase chain reaction.

\section{References}

1. Noreldin A, Mohamed A, Abdelaziz A, Ali G: Correlation between Liver Function Tests and Polymerase Chain Reaction in Chronic Hepatitis C Patients. J Hepatol Gastroint Dis 2015, 1(110):2.

2. Mohd Hanafiah K, Groeger J, Flaxman AD, Wiersma ST: Global epidemiology of hepatitis C virus infection: new estimates of age-specific antibody to HCV seroprevalence. Hepatology 2013, 57(4):1333-1342.

3. Kumthip K, Maneekarn N: The role of HCV proteins on treatment outcomes. Virology journal 2015, 12(1):217.

4. Bawazir A, AlGusheri F, Jradi H, AlBalwi M, Abdel-Gader A-G: Hepatitis $\mathrm{C}$ virus genotypes in Saudi Arabia: a future prediction and laboratory profile. Virology journal 2017, 14(1):208. 
5. Shahid M, Idrees M, Nasir B, Raja AJ, Raza SM, Amin I, Rasul A, Tayyab GU: Correlation of biochemical markers and HCV RNA titers with fibrosis stages and grades in chronic HCV-3a patients. European journal of gastroenterology \& hepatology 2014, 26(7):788-794.

6. Nolandt O, Kern V, Muller H, Pfaff E, Theilmann L, Welker R, Krausslich HG: Analysis of hepatitis C virus core protein interaction domains. The Journal of general virology 1997, 78 ( Pt 6):1331-1340.

7. Nazir N, Jan MR, Ali A, Asif M, Idrees M, Nisar M, Zahoor M, Abd El-Salam NM: Prevalence of hepatitis-C virus genotypes and potential transmission risks in Malakand Khyber Pakhtunkhwa, Pakistan. Virol J 2017, 14(1):160.

8. Ait-Goughoulte M, Hourioux C, Patient R, Trassard S, Brand D, Roingeard P: Core protein cleavage by signal peptide peptidase is required for hepatitis $C$ virus-like particle assembly. The Journal of general virology 2006, 87(Pt 4):855-860.

9. Kao CC, Yi G, Huang HC: The core of hepatitis C virus pathogenesis. Current opinion in virology 2016, 17:66-73.

10. Yan XB, Battaglia S, Boucreux D, Chen Z, Brechot C, Pavio N: Mapping of the interacting domains of hepatitis $\mathrm{C}$ virus core protein and the double-stranded RNA-activated protein kinase PKR. Virus research 2007, 125(1):79-87.

11. Spaziani A, Alisi A, Sanna D, Balsano C: Role of p38 MAPK and RNA-dependent protein kinase (PKR) in hepatitis $\mathrm{C}$ virus core-dependent nuclear delocalization of cyclin B1. The Journal of biological chemistry 2006, 281(16):10983-10989.

12. Melen $K$, Fagerlund R, Nyqvist $M$, Keskinen $P$, Julkunen I: Expression of hepatitis $C$ virus core protein inhibits interferon-induced nuclear import of STATs. Journal of medical virology 2004, 73(4):536-547.

13. Ghany MG, Strader DB, Thomas DL, Seeff LB, American Association for the Study of Liver D: Diagnosis, management, and treatment of hepatitis C: an update. Hepatology 2009, 49(4):13351374.

14. Chhatwal J, He T, Hur C, Lopez-Olivo MA: Direct-Acting Antiviral Agents for Patients With Hepatitis C Virus Genotype 1 Infection Are Cost-Saving. Clinical gastroenterology and hepatology : the official clinical practice journal of the American Gastroenterological Association 2017, 15(6):827-837 e828.

15. Buhler S, Bartenschlager R: New targets for antiviral therapy of chronic hepatitis C. Liver international : official journal of the International Association for the Study of the Liver 2012, 32 Suppl 1:9-16.

16. Aghemo A, De Francesco R: New horizons in hepatitis $C$ antiviral therapy with direct-acting antivirals. Hepatology 2013, 58(1):428-438.

17. Kowdley KV, Lawitz E, Crespo I, Hassanein T, Davis MN, DeMicco M, Bernstein DE, Afdhal N, Vierling $\mathrm{JM}$, Gordon SC et al: Sofosbuvir with pegylated interferon alfa-2a and ribavirin for treatment-naive patients with hepatitis $\mathrm{C}$ genotype-1 infection (ATOMIC): an open-label, randomised, multicentre phase 2 trial. Lancet 2013, 381(9883):2100-2107.

18. Lawitz E, Lalezari JP, Hassanein T, Kowdley KV, Poordad FF, Sheikh AM, Afdhal NH, Bernstein DE, Dejesus $E$, Freilich $B$ et al: Sofosbuvir in combination with peginterferon alfa-2a and ribavirin for non- 
cirrhotic, treatment-naive patients with genotypes 1, 2, and 3 hepatitis $C$ infection: a randomised, double-blind, phase 2 trial. The Lancet Infectious diseases 2013, 13(5):401-408.

19. Shao RX, Zhang L, Peng LF, Sun E, Chung WJ, Jang JY, Tsai WL, Hyppolite G, Chung RT: Suppressor of cytokine signaling 3 suppresses hepatitis $C$ virus replication in an mTOR-dependent manner. Journal of virology 2010, 84(12):6060-6069.

20. Lin W, Choe WH, Hiasa Y, Kamegaya Y, Blackard JT, Schmidt EV, Chung RT: Hepatitis C virus expression suppresses interferon signaling by degrading STAT1. Gastroenterology 2005, 128(4):1034-1041.

21. Lin W, Kim SS, Yeung E, Kamegaya Y, Blackard JT, Kim KA, Holtzman MJ, Chung RT: Hepatitis C virus core protein blocks interferon signaling by interaction with the STAT1 SH2 domain. Journal of virology 2006, 80(18):9226-9235.

22. Guss D, Sherigar J, Rosen P, Mohanty SR: Diagnosis and Management of Hepatitis C Infection in Primary Care Settings. Journal of general internal medicine 2018, 33(4):551-557.

23. Ahmed A, Felmlee DJ: Mechanisms of Hepatitis C Viral Resistance to Direct Acting Antivirals. Viruses 2015, 7(12):6716-6729.

24. Haid S, Novodomska A, Gentzsch J, Grethe C, Geuenich S, Bankwitz D, Chhatwal P, Jannack B, Hennebelle T, Bailleul F et al: A plant-derived flavonoid inhibits entry of all HCV genotypes into human hepatocytes. Gastroenterology 2012, 143(1):213-222 e215.

25. Kumar RS, Rajkapoor B, Perumal P: In vitro and in vivo anticancer activity of Indigofera cassioides Rottl. Ex. DC. Asian Pacific journal of tropical medicine 2011, 4(5):379-385.

26. Shinwari Z, Watanabe T, Rehman M, Youshikawa T: A pictorial guide to Medicinal Plants of Pakistan. KUST Kohat, Pakistan 2006.

27. Shahjahan M, Vani G, Devi CS: Protective effect of Indigofera oblongifolia in CCl4-induced hepatotoxicity. Journal of medicinal food 2005, 8(2):261-265.

28. Kumar RS, Rajkapoor B, Perumal P: Antitumor and cytotoxic activities of methanol extract of Indigofera linnaei Ali. Asian Pacific journal of cancer prevention : APJCP 2011, 12(3):613-618.

29. Ravichandran KR, R.: The Antiproliferative Activity of Flavanoidal Fraction of Indigofera tinctoria is Through Cell Cycle Arrest and Apoptotic Pathway in A-549 Cells. J Biol Sci 2008, 8:584-590.

30. Claimer CS, Mahesh A, Sinilal B, Rao DM, Thangadurai D: Protective Effect of Indigofera Aspalathoides Roots on N-Nitrosodiethylamine-induced Hepatocarcinogenesis in Mice. Indian journal of pharmaceutical sciences 2012, 74(2):157-160.

31. Christina AJ, Alwin Jose M, Heison Robert SJ, Kothai R, Chidambaranathan N, Muthumani P: Effect of Indigofera aspalathoides against Dalton's ascitic lymphoma. Fitoterapia 2003, 74(3):280-283.

32. Rajkapoor B, Jayakar B, Kavimani S, Murugesh N: Protective effect of Indigofera aspalathoides against CCl4-induced hepatic damage in rats. Journal of herbal pharmacotherapy 2006, 6(1):49-54.

33. Rajkapoor B, Murugesh N, Chodon D, Sakthisekaran D: Chemoprevention of N-nitrosodiethylamine induced phenobarbitol promoted liver tumors in rat by extract of Indigofera aspalathoides. Biological 
\& pharmaceutical bulletin 2005, 28(2):364-366.

34. Sivagnanam SK, Rao MR, Balasubramanian MP: Chemotherapeutic Efficacy of Indigofera aspalathoides on 20-Methylcholanthrene-Induced Fibrosarcoma in Rats. ISRN pharmacology 2012, 2012:134356.

35. Kumar SS, Karrunakaran CM, Rao MR, Balasubramanian MP: Inhibitory effects of Indigofera aspalathoides on 20-methylcholanthrene-induced chemical carcinogenesis in rats. Journal of carcinogenesis 2011, 10:1.

36. Gul A, Zahid N, Ahmed J, Zahir F, Khan IA, Ali I: Molecular characterization of Hepatitis C virus 3a in Peshawar. BMC infectious diseases 2016, 16(1):163.

37. Yahya F, Mamat S, Kamarolzaman M, Seyedan A, Jakius K, Mahmood N, Shahril M, Suhaili Z, Mohtarrudin N, Susanti D: Hepatoprotective activity of methanolic extract of Bauhinia purpurea leaves against paracetamol-induced hepatic damage in rats. Evidence-Based Complementary and Alternative Medicine 2013, 2013.

38. Morozov VA, Lagaye S: Hepatitis C virus: Morphogenesis, infection and therapy. World journal of hepatology 2018, 10(2):186-212.

39. Gower E, Estes C, Blach S, Razavi-Shearer K, Razavi H: Global epidemiology and genotype distribution of the hepatitis C virus infection. Journal of hepatology 2014, 61(1):S45-S57.

40. Arshad A, Ashfaq UA: Epidemiology of hepatitis $C$ infection in Pakistan: current estimate and major risk factors. Critical Reviews ${ }^{T M}$ in Eukaryotic Gene Expression 2017, 27(1).

41. Rattanavipapong W, Anothaisintawee T, Teerawattananon Y: Revisiting policy on chronic HCV treatment under the Thai Universal Health Coverage: An economic evaluation and budget impact analysis. PloS one 2018, 13(2):e0193112.

42. Al-abadi B, Al-hiary M, Khasawneh R, Bani-Salameh A, Al-saeidat S, Nouar ZA, Masaroh G: Frequency of Hepatitis $C$ Virus Genotypes and Genotype Association with Hepatitis C Virus Load, age and gender, King Hussein Medical Center Experience. JOURNAL OF THE ROYAL MEDICAL SERVICES 2018, 25(3):51.

43. Nadeem A, Hussain MM, Aslam M: Correlation of serum alanine aminotransferase and aspartate aminotransferase levels to liver histology in chronic hepatitis C. J Coll Physicians Surg Pak 2010, 20(10):657-661.

44. Bradshaw D, Vasylyeva T, Davis C, Pybus O, Theze J, Thomson E, Martinello M, Matthews G, Burholt R, Gilleece Y: Risk factors and patterns of HCV transmission amongst men who have sex with men. In: HIV MEDICINE: 2019. WILEY 111 RIVER ST, HOBOKEN 07030-5774, NJ USA: 12-12.

45. Crowley D, Lambert JS, Betts-Symonds G, Cullen W, Keevans M, Kelly E, Laird E, McHugh T, McKiernan S, Miggin SJ: The seroprevalence of untreated chronic hepatitis $\mathrm{C}$ virus (HCV) infection and associated risk factors in male Irish prisoners: a cross-sectional study, 2017. Eurosurveillance 2019, 24(14).

46. Jovanović-Ćupić SP, Glišić S, Stanojevic M, Vasiljevic N, Bojić T, Božović AM, Dimitrijević BB: Response factors to pegylated interferon-alfa/ribavirin treatment in chronic hepatitis $c$ patients 
genotype 1b. Archives of biological sciences 2014, 66(1):193-201.

47. Ahmad W, ljaz B, Javed FT, Kausar H, Sarwar MT, Gull S, Asad S, Shahid I, Hassan S: HCV genotypespecific correlation with serum markers: higher predictability for genotype 4a. Virology journal 2011, 8(1):293.

48. Irshad M, Gupta P, Irshad K: Molecular targeting of antiviral drugs used against hepatitis $C$ virus infection. Hepatoma Res 2018, 4:23.

49. Aghemo A, Rumi MG, Soffredini R, D’Ambrosio R, Ronchi G, Del Ninno E, Gallus S, Colombo M: Impaired response to interferon-alpha2b plus ribavirin in cirrhotic patients with genotype 3a hepatitis C virus infection. Antiviral therapy 2006, 11(6):797.

50. Khan S, Ali I, Badshah M, Khan QM, Haider ZN, Ali S, Khan IA, Ullah A: Molecular Epidemiology of Hepatitis C Virus Genotypes Among Chronically Infected Patients in Pakistan. Jundishapur Journal of Microbiology 2019, 12(3):1-7.

51. Waheed YS, M.: Elimination of hepatitis from Pakistan by 2030: is it possible? Hepatoma Res 2018, 4(45).

52. Takahashi M, Yamada G, Miyamoto R, Doi T, Endo H, Tsuji T: Natural course of chronic hepatitis C. The American journal of gastroenterology 1993, 88(2):240-243.

53. Raza SM, H. Farooqi, S. : Review: epidemic status of HCV in Pakistan. GlobJof EnginScience and Research Manage 2015, 12(2).

54. Afzal MS, Khan MY, Ammar M, Anjum S, Zaidi NU: Diagnostically untypable hepatitis C virus variants: it is time to resolve the problem. World journal of gastroenterology 2014, 20(46):1769017692.

55. Ruan Y, Qin G, Yin L, Chen K, Qian HZ, Hao C, Liang S, Zhu J, Xing H, Hong K et al: Incidence of HIV, hepatitis $\mathrm{C}$ and hepatitis $\mathrm{B}$ viruses among injection drug users in southwestern China: a 3-year follow-up study. Aids 2007, 21 Suppl 8:S39-46.

56. Al-Tawfiq JA, Anani A: Profile of viral hepatitis A, B, and C in a Saudi Arabian hospital. Medical science monitor : international medical journal of experimental and clinical research 2008 , 14(1):CR52-56.

57. Roingeard $\mathrm{P}$, Hourioux $\mathrm{C}$ : Hepatitis $\mathrm{C}$ virus core protein, lipid droplets and steatosis. Journal of viral hepatitis 2008, 15(3):157-164.

58. Chan LP, Chou TH, Ding HY, Chen PR, Chiang FY, Kuo PL, Liang CH: Apigenin induces apoptosis via tumor necrosis factor receptor- and Bcl-2-mediated pathway and enhances susceptibility of head and neck squamous cell carcinoma to 5-fluorouracil and cisplatin. Biochimica et biophysica acta 2012, 1820(7):1081-1091.

59. Mafuvadze B, Liang Y, Besch-Williford C, Zhang X, Hyder SM: Apigenin induces apoptosis and blocks growth of medroxyprogesterone acetate-dependent BT-474 xenograft tumors. Hormones \& cancer 2012, 3(4):160-171.

60. Shukla S, MacLennan GT, Flask CA, Fu P, Mishra A, Resnick MI, Gupta S: Blockade of beta-catenin signaling by plant flavonoid apigenin suppresses prostate carcinogenesis in TRAMP mice. Cancer 
research 2007, 67(14):6925-6935.

61. Nicholas C, Batra S, Vargo MA, Voss OH, Gavrilin MA, Wewers MD, Guttridge DC, Grotewold E, Doseff Al: Apigenin blocks lipopolysaccharide-induced lethality in vivo and proinflammatory cytokines expression by inactivating NF-kappaB through the suppression of p65 phosphorylation. Journal of immunology 2007, 179(10):7121-7127.

62. Ohno M, Shibata C, Kishikawa T, Yoshikawa T, Takata A, Kojima K, Akanuma M, Kang YJ, Yoshida H, Otsuka $\mathrm{M}$ et al: The flavonoid apigenin improves glucose tolerance through inhibition of microRNA maturation in miRNA103 transgenic mice. Scientific reports 2013, 3:2553.

63. Jardim ACG, Shimizu JF, Rahal P, Harris M: Plant-derived antivirals against hepatitis c virus infection. Virol J 2018, 15(1):34.

64. Mossa JS, Tariq M, Mohsin A, Ageel AM, al-Yahya MA, al-Said MS, Rafatullah S: Pharmacological studies on aerial parts of Calotropis procera. The American journal of Chinese medicine 1991, 19(34):223-231.

65. Mascolo N, Sharma R, Jain SC, Capasso F: Ethnopharmacology of Calotropis procera flowers. Journal of ethnopharmacology 1988, 22(2):211-221.

66. Rehman S, Ashfaq UA, Riaz S, Javed T, Riazuddin S: Antiviral activity of Acacia nilotica against Hepatitis C Virus in liver infected cells. Virol J 2011, 8:220.

67. Ashfaq UA, Idrees S: Medicinal plants against hepatitis C virus. World journal of gastroenterology 2014, 20(11):2941-2947.

\section{Tables}

Table 1: Gender wise distribution of HCV genotypes among age groups $(n=421)$.

\begin{tabular}{|c|c|c|c|c|}
\hline HCV Genotype & \multicolumn{2}{|c|}{ Gender } & \multicolumn{2}{c|}{ Different age groups } \\
\hline & Male & Female & $20-40$ yrs & $\geq 40$ yrs \\
\hline 3a & $207(49 \%)$ & $156(37 \%)$ & $338(93.11 \%)$ & $25(6.8 \%)$ \\
\hline 1A & $22(5 \%)$ & $13(3 \%)$ & $33(94.2 \%)$ & $2(5.7 \%)$ \\
\hline 3b & $1(0.20 \%)$ & $1(0.20 \%)$ & $2(100 \%)$ & 0 \\
\hline 1b & $2(0.40 \%)$ & $3(0.70 \%)$ & $5(100 \%)$ & 0 \\
\hline Untypable & $8(2 \%)$ & $7(2 \%)$ & $10(66.6 \%)$ & $5(33 \%)$ \\
\hline Mixed & $1(0.20 \%)$ & $0(0.0 \%)$ & $1(100 \%)$ & 0 \\
\hline Total & $241(57.24 \%)$ & $180(42.76 \%)$ & $389(92.4 \%)$ & $32(7.6 \%)$ \\
\hline
\end{tabular}

Table 2: Mean and standard deviation of AST, ALT and total bilirubin in HCV genotypes. 


\begin{tabular}{|c|c|c|c|c|}
\hline HCV & Total No. of patients & ALT(IU/L) & AST(IU/L) & Total Bilirubin(mg/dl) \\
\hline 3a & 363 & $44.19 \pm 10.36$ & $43.64 \pm 9.73$ & $1.02 \pm .12$ \\
\hline 1a & 35 & $44.34 \pm 11.52$ & $45.14 \pm 10.11$ & $1.04 \pm .13$ \\
\hline 1b & 5 & $39.80 \pm 14.73$ & $41.40 \pm 15.32$ & $1.06 \pm .19$ \\
\hline 3b & 2 & $62.00 \pm 4.24$ & $66.00 \pm 0.00$ & $1.20 \pm 0.00$ \\
\hline Mix & 1 & $44.00 \pm 0.00$ & $44.00 \pm 0.00$ & $1.00 \pm 0.00$ \\
\hline Untypable & 15 & $47.73 \pm 9.33$ & $48.13 \pm 8.85$ & $1.04 \pm 0.12$ \\
\hline
\end{tabular}

*AST $=$ Aspartate transaminase, $*$ ALT Alanine transaminase

Table 3: HCV Viral loads in genotype3a

\begin{tabular}{|l|l|l|l|}
\hline Genotype 3a & Low & High & P Value \\
\hline Viral Load & $<800,000$ & $>800,000$ & $<0.05$ \\
\hline Total Patients & 90 & 273 & \\
\hline
\end{tabular}

\section{Figures}

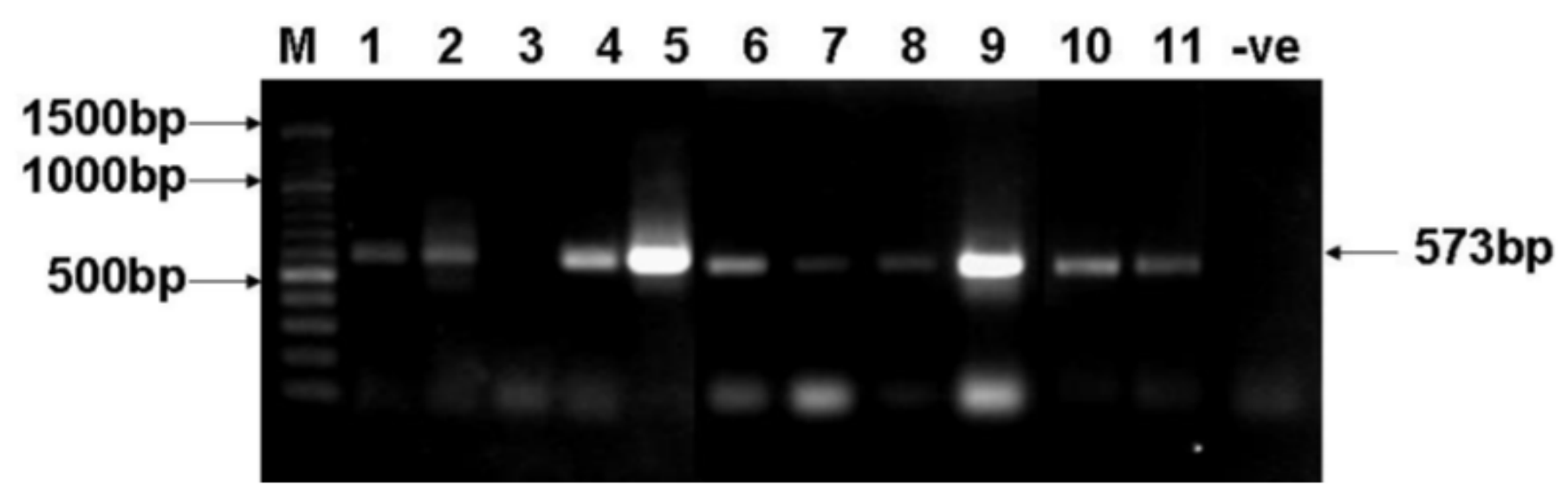

Figure 1

HCV core gene amplification through PCR. Core gene of HCV 3a genotype from patients' serum samples. Sample 1, 2, 4, 5, 6, 7, 8, 9, 10 and 11 shows amplified PCR product of core gene (573bp) 100bp DNA size Marker (M) and PCR negative. 
Sequence Translation

Translated

Core

Protein

1-64

1. KY364192-Pakistan

2. KY434060-Pakistan

3. MF838728-Pakistan

4. MF838729-Pakistan

5. MF838730.Pakistan

6. MF838731-Pakistan

7. MF838732-Pakistan

8. MG-977454-Pakistan

9. MG-977455-Pakistan

MSTLPTLQRKTQKNTIRRPQDVKFPGGGQIVGGVYVLPRRGPRLGVRATRKTSERSQPRGRRQP MSTLPTLQRKTQKNTIRRPQDVKFPGQGQILGGVYVLPRRGPRMGVRATRKTSERSQPRGRRQP MSTLPTLQRKTQKNTIRRPQDVKFPGGGQIVGGVYVLPRRGPRLGVRATRKTSERSQPRGRRGP MSTLPTLQRKTQKNTIRRPQDVKFPGGGQIVGGVYVLPRRGPRLGVRATRKTSERSQPRGRRQP MSTLPTLQRKTQKNTIRRPQDVKFPGGGQIVGGVYVLPRRGPRLGVRATRKTSERSQPRGRRQP MSTLPTLQRKTQKNTIRRPQDVKFPGGGQIVGGVYVLPRRGPRLGVRATRKTSERSQPRGRRQP MSTLPTLQRKTQKNTIRRPQDVKFPGGGQIVGGVYVLPRRGPRLGVRATRKTSERSQPRGRRQP MSTLPKLQRKTQKNTIRRPQDVKFPGGGQIVGGVYVLPRRGPRLGVRTTRKTSERSQPRGRRQP MSTLPTLQRKTKRNTIRRPQDVKFPGGGQIVGGVYVLPRRGPRLGVCATRKTSERSQPRGRRQP

Translated Core Protein 65-126

1. KY364192-Pakistan 2. KY434060.Pakistan 3. MF838728-Pakistan 4. MF838729.Pakistan 5. MF838730-Pakistan 6. MF838731-Pakistan 7. MF838732-Pakistan 8. MG-977454-Pakistan 9. MG-977455-Pakistan

I PKARRSDGRSWAQPGYPWPLYGNEGCGWAGWLLSPRGSRPSWGPNDPRRRSRNLGKVIDTL I PKARRS D GPSWA QPGYPWPLYGNEGCGWAGWVLSPRGSRPSWGPNDPRRRSRNLGKVIDTL I PKARRSDGRSWAQPGYPWPLYGNEGCGWAGWLLSPRGSRPSWGPNDPRRRSRNLGKVIDTL I PKARRSDGRSWAQPGYPWPLYGNEGCGWAGWLLSPRGSRPSWGPNDPRRRSRNLGKVIDTL I PKARRSDGRSWAQPGYPWPLYGNEGCGWAGWLLSPRGSRPSWGPNDPRRRSRNLGKVIDTL I PKARRSDGRSWAQPGYPWPLYGNEGCGWAGWLLSPRGSRPSWGPNDPRRRSRNLGKVIDTL I PKARRSDGRSWAQPGYPWPLYGNEGCGWAGWLLSPRGSRPSWGPNDPRRRSRNLGKVIDTL I PKARRSDGRSWAQPGYPWPLYGNEGCGWAGWLLSPRGSRPSWGPNDPRRRSRNLGKVIDTL I PKARRSEGRSWAQPGYPWPLYGNEGCGWAGWLLSPRGSRPSWGPNDPRRRSRNLGKVIDTL

Translated Core Proteins 127-191

1. KY364192-Pakistan

2. KY434060-Pakistan

3. MF838728-Pakistan

4. MF838729-Pakistan

5. MF838730-Pakistan

6. MF838731-Pakistan

7. MF838732-Pakistan

8. MG-977454-Pakistan

9. MG-977455-Pakistan

TCGFADLMGYIPLVGAPVGGVARALAHGVRALEDGINFATGNLPGCSFSIFLLALLSCLIHPTAC TCGFADLMGYIPLVRAPVGOVARALAHGVRALEDGINFATGNLPGCSFSIFLLALLSSLIHPTAC TCGFADLMGYIPLVGAPVGGVARALAHGVRALEDGINFATGNLPGCSFSIFLLALLSCLIHPTAC TCGFADLMGYIPLVOAPVGGVARALAHGVRALEDGINFATGNLPGCSFSIFLLALLSCLIHPTAC TCGFADLMGYIPLVGAPVGGVARALAHGVRALEDGINFATGNLPGCSFSIFLLALLSCLIHPTAC TCGFADLMGYIPLVGAPVGGVARALAHGVRALEDGINFATGNLPGCSFSIFLLALLSCLIHPTAC TCGFADLMGYIPLVGAPVGGVARALAHGVRALEDGINFATGNLPGCSFSIFLLALLSCLIHPTAC TCGFADLMGYIPLVGAPVGGVARALAHGVRALEDGINFATGNLPGCSFSIFLLALLSCLIHPTAS TCGFADLMGYIPLVGAPVGGVARALAHGVRALEDGINFATGNLPGCSFSIFLLALLSCLIHPTAG

Figure 2

Translated HCV core gene sequences 


\section{Toxicity of extract of Indigoferra gerardiana}

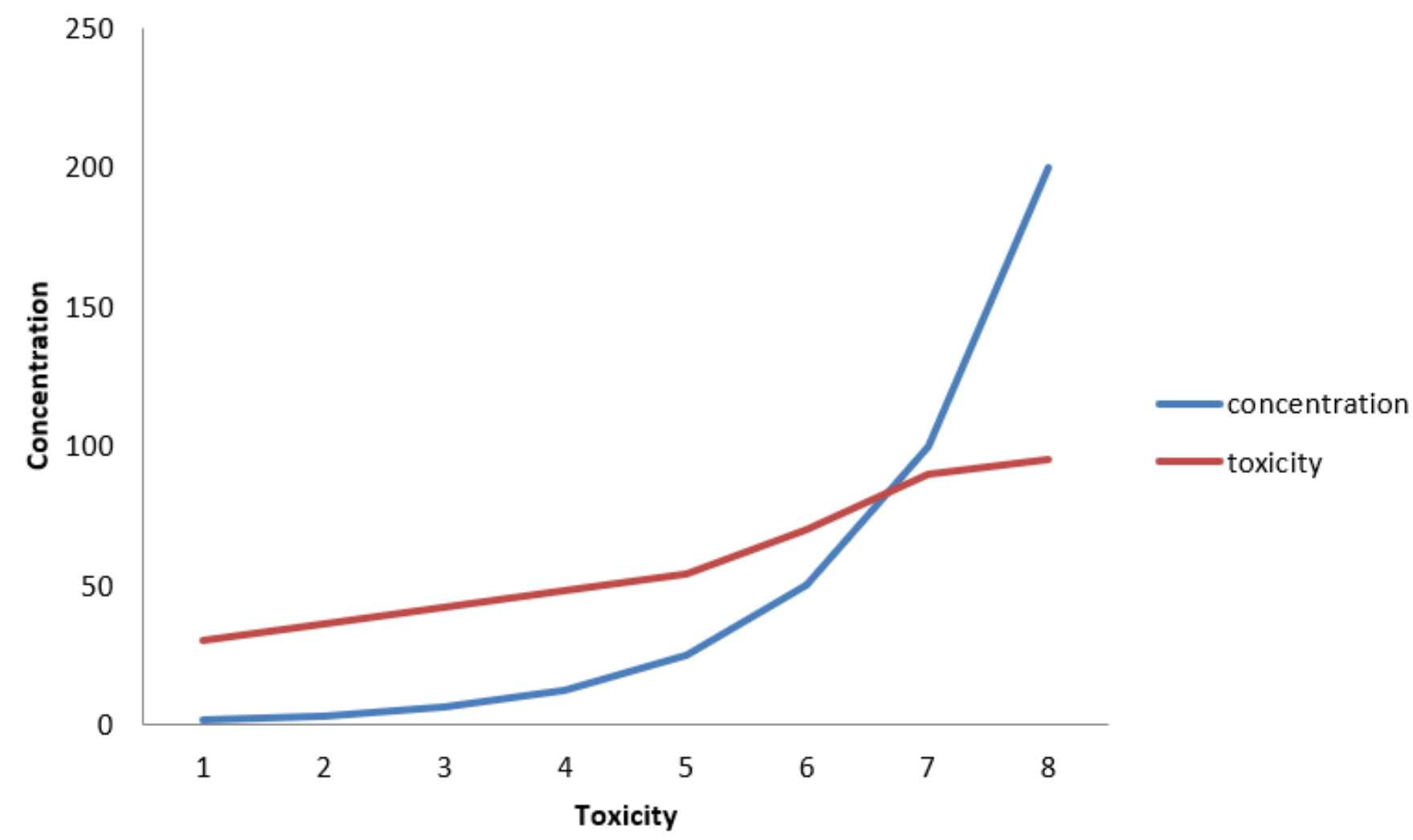

Figure 3

Cellular Toxicity through MTT cell proliferation assay; Toxicity of extract of IG: At different concentrations of the herbal extracts the cell lines were incubated. Absorbance readings were taken through microplate spectrophotometer at the end of incubation period. 


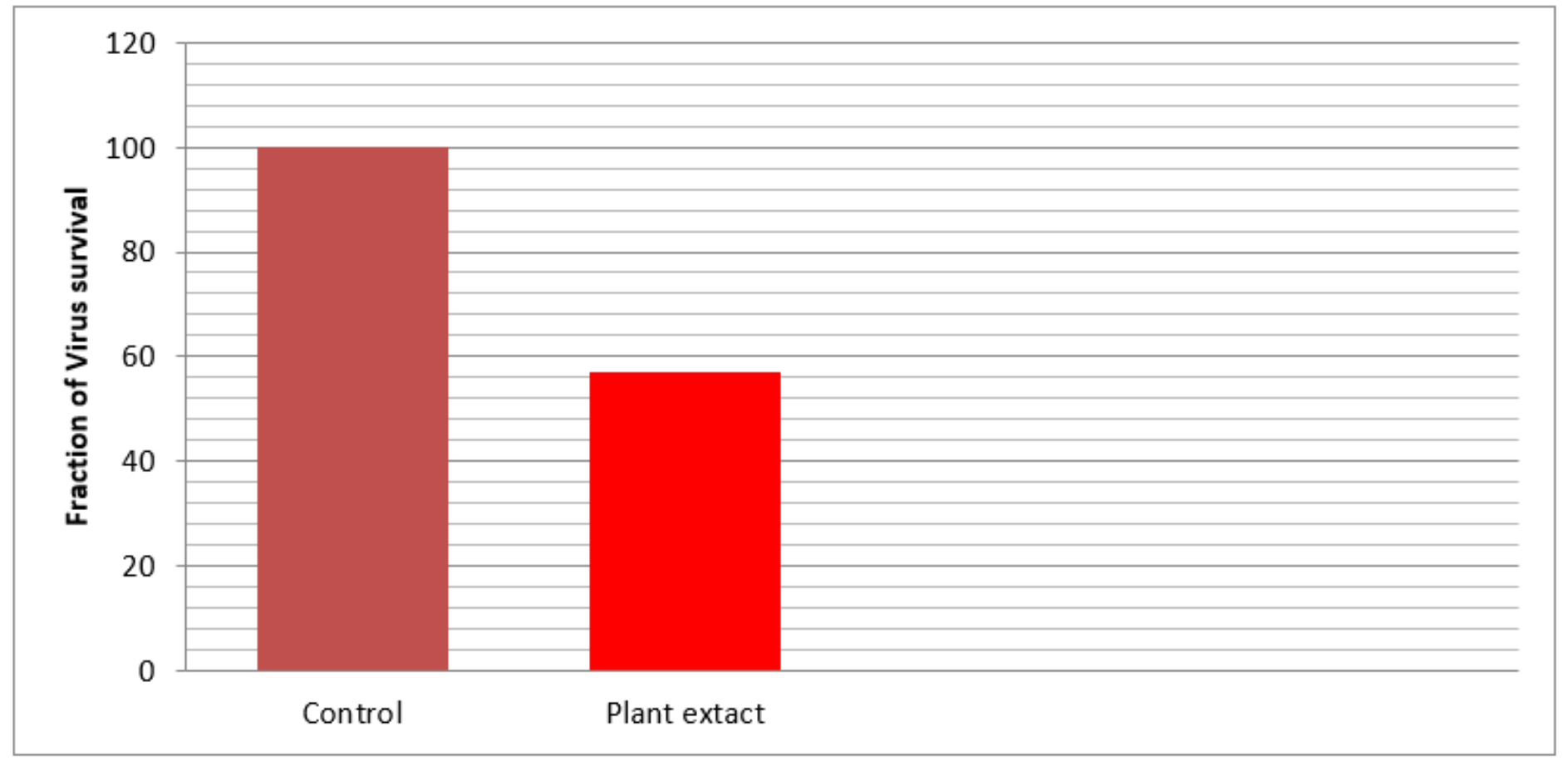

Figure 4

Anti-HCV activity of extract IG. Cell lines were transfected and incubated for $24 \mathrm{~h}$. At the end of incubation period, expression of gene of interest was determined by the Q-PCR assay and are shown in Fig 4 relative to the levels of cells incubated without compound (control) The results demonstrated that IG resulted in $57 \%$ inhibition of cell line at nontoxic concentration.

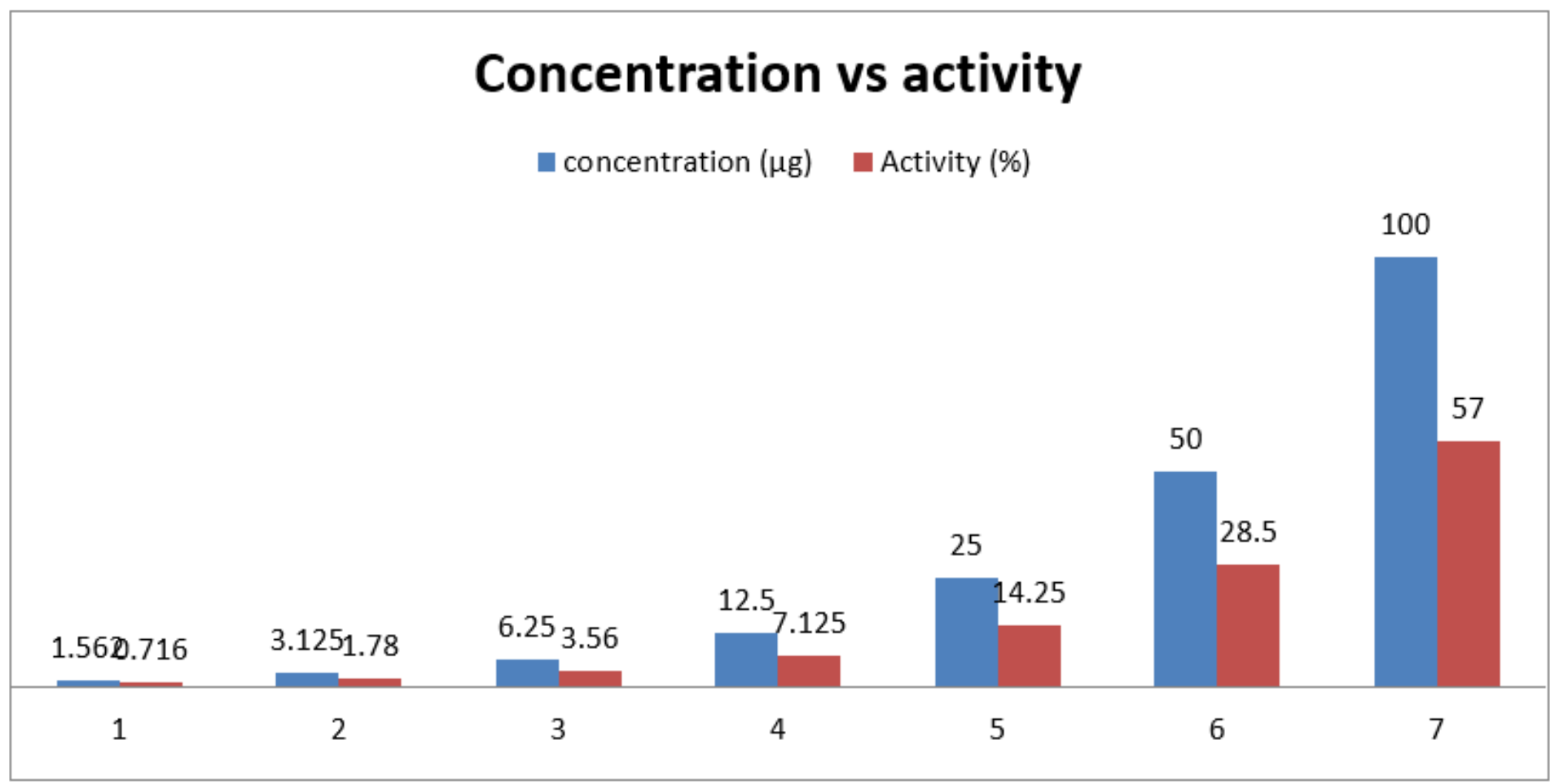

Figure 5 
Different concentrations of acetone extract impeded viral titer to $57 \%$.

Page 22/22 